\title{
The effect of the modeling approach to enhance knowledge and skill of lactation management among primipara's mother
}

\author{
Lina Oktalesmana $^{1 *}$; Zainal Munir ${ }^{2}$; Wiwin Nursiam ${ }^{3}$ \\ ${ }^{1 * 2,3}$ Health Faculty of Nurul Jadid University
}

\section{ARTICLE INFO}

Article history:

Received September 24, 2019

Revised November 09, 2019

Accepted November 22, 2019

\author{
Keyword: \\ Primiparous Mothers \\ Skill \\ Health Education \\ Knowledge \\ Modelling Technic \\ *) corresponding author \\ Lecturer of Health Faculty \\ Nurul Jadid University \\ Jl. PP Nurul Jadid, Dusun Tj. Lor, \\ Karanganyar, Kec. Paiton, Probolinggo, \\ Jawa Timur 67291
}

Email: linaokta.1010@gmail.com

DOI: https://doi.org/10.30604/jika.v4i2.232

\begin{abstract}
A B S T R A C T
A modeling approach to lactation management is a learning effort undertaken by mothers, fathers and families to support the success of breastfeeding by watching and paying attention to other people's behavior and then copying it. The purpose of this research was to analyze the knowledge and skills of primiparous mothers about lactation management before and after the modeling approach. This research method uses pre-experiment with one-group pre-post test design. The research population was all primiparous mothers whose babies were treated in level 2 perinatology, which were taken as accidental sampling involving 26 primiparous mothers. The method used in health education (penkes) is the Modeling approach with pantom tools, modules, and containers / bottles that have a lid. The modeling approach consists of four processes, namely Attention, Retention, Reproduction motori (reproduction), and motivation (motivation). The results showed that there was a significant influence between the modeling approach to the knowledge and skills of primiparous mothers in the perinatology room of Bondowoso Hospital.
\end{abstract}

\section{INTRODUCTION}

Lactation management is an effort made by mother, father and family to support the success of breastfeeding (Dwi, 2012). WHO data in 2015, exclusive breastfeeding in 
infants aged 0-6 months in Indonesia only $36 \%$ (Astuti, 2018). In Indonesia exclusive breastfeeding is only $35 \%$, this has not yet reached the target of exclusive breastfeeding with a 50\% amount in the process of exclusive breastfeeding which is mostly done for 1-6 hours after birth (35.2\%) and the lowest occurs in 7-23 hours after births in the amount of $3.7 \%$ (InfoDatin, 2018). According to Polman data (2014) shows that based on the World Breastfeeding Trends Initiative (2012) only $25.7 \%$ of mothers in Indonesia succeeded in giving exclusive breastfeeding for 6 months (Wattimena \& Werdani, 2015). Based on data from East Java Province, only $34.92 \%$ of newborns get exclusive breastfeeding (Dinkes, East Java, 2016). Overall achievement in East Java is only $74 \%$ so that it has not met the target set of $77 \%$, while Bondowoso district it only reaches the target 70\% (District Health Office, Bondowoso, 2018).

Based on data from a coordination meeting conducted on February 15, 2019 in the perinatology room of Bondowoso Hospital, with direct interviews with 5 primiparous 3 mothers, they were reluctant to breastfeed because they could not hold a baby, breast milk was still not coming out, and when breastfeeding the baby would continue to sleep so that it would not continue want to suckle. And out of these 5 people, only 2 people know the benefits and benefits of exclusive breastfeeding.

Lactation management is an effort made by mothers to achieve success in exclusive breastfeeding (Dwi, 2012). The scope of lactation management in the postnatal period includes exclusive breastfeeding, breastfeeding techniques, expressing milk, giving squeezed breast milk, storing squeezed breast milk, and fulfilling nutrition during the mother's breastfeeding period. In primiparous mothers, this process is sometimes often forgotten, resulting in the production of breast milk is not optimal and results in a decrease in exclusive breastfeeding coverage (Arini, H, 2012)
Education is a human guide to act and fill a life that can be used to obtain information, so as to improve the quality of life. In exclusive breastfeeding by providing health education on lactation management to primiparous mothers. (Notoatmodjo, 2014)

Health education is a health effort that aims to help individuals to be able to independently or in groups in achieving healthy living goals (Zaidin Ali, 2010). Learning through a modeling approach consists of four processes, namely attention, attention, retention, reproduction, and motivation (Bandura, 1977). Learning through a modeling approach consists of four processes, namely Attention (attention) where nurses increase the attention of mothers, then begin to have a relationship of mutual trust by digging up information and asking what are the problems and obstacles of the mother associated with breastfeeding, then the retention. The efforts made by providing health material with a variety of learning methods, among others, demonstration, redemontration, and simulation using various learning media, then continued reproduction (reproduction), namely the process of remembering and practicing again that was delivered at the time of health and the last is motivation (motivation), namely the mother can show her potential and self-confidence arises the mother to give milk to her baby (Bandura, 1977).

From the research conducted in Maros district, it was concluded that health education with modeling methods can increase knowledge, skills, practice abilities, maternal confidence in breastfeeding and stimulating babies, which in turn can optimize the growth and development of infants (Ariyanti Saleh, 2017)

This research aims to analyze the characteristics of primiparous mothers based on age, education, occupation, information acquisition, and experience. Analyzing the knowledge and skills of primiparous mothers about lactation management before and after 
the modeling approach and aims to analyze the influence of the modeling approach on the knowledge and skills of primiparous mothers about lactation management.

\section{METHOD}

This research uses quantitative methods with Pre-Experimental which uses pre-post test design in one group (one-group pre-post test design). The independent variable is a modeling method of lactation management while the dependent variable is knowledge and skills. The research was conducted 1 month, ie from 1 to 30 May 2019 assisted by 2 level 2 perinatology room nurses. The sampling technique used accidental sampling. The inclusion criteria in this research were primiparous mothers whose babies were treated in perinatology, primiparous mothers aged 20-35 years, primiparous mothers with elementary to high school education, primiparous mothers who had never breastfeeded, and primiparous mothers who were willing to be respondents with as many samples 26 respondents.

The method used in health education (penkes) is a Modeling approach with pantom tools, modules, and containers / bottles that have a baby pantom cap as a baby parable, a module that contains lactation management made by researchers, and glass containers / bottles which has a lid as a place of breast milk, with the first step the researcher distributes questionnaires about lactation management and observes by looking at and asking primiparous mothers to practice how to wash hands, clean the breast before breastfeeding, apply breast milk to the areola before breastfeeding and how to milk the baby, burping the baby after breastfeeding, the second stage of the nurses perinatology room provides education and demonstrates the correct way of lactation management, then the third stage researchers and nurses give back questionnaires about lactation management, observing and instructing primiparous mothers to practice lactation management methods, After that researchers compare the results before and after modeling.

The instrument used in this research was a questionnaire containing 15 questions, an observation sheet and an interview containing 18 questions to find out the primiparous mother's skills which were adapted from a book written by Nursalam. The instrument used in this research was a mother's knowledge questionnaire about lactation management which contained 15 questions and observation sheets and interviews of mother's actions in lactation management which contained 18 questions that discussed the understanding, benefits of breastfeeding, how to breastfeed, food that must be consumed by adapted mothers from a book written by Nursalam, 2014). The variables measured before and after the intervention were knowledge and skills of primiparous mothers about lactation management. The analysis used is univarat and bivarat. The results obtained were tested using Wilcoxon test, data presentation using tables and explained descriptively.

\section{RESULTS AND DISCUSSION}

The results of this research will explain the results of the research and discussion of the picture of nonpharmacological treatment in dealing with atheistic rheumatoid pain in the elderly in the arrowroot elderly rehabilitation service unit. The results of the research are presented in tabular form that illustrates the frequency distribution

\section{Tabel 1.}


Table 1

Characteristics of Research Respondents

\begin{tabular}{|c|c|c|}
\hline Characteristic responding & Frequency & $(\%)$ \\
\hline \multicolumn{3}{|l|}{ Age } \\
\hline $20-25$ year & 14 & 53.8 \\
\hline $25-30$ year & 8 & 30.8 \\
\hline $30-35$ year & 4 & 15.4 \\
\hline \multicolumn{3}{|l|}{ Education } \\
\hline SD & 5 & 19.2 \\
\hline SMP & 12 & 46.2 \\
\hline SMA & 9 & 34.6 \\
\hline \multicolumn{3}{|l|}{ Job } \\
\hline Housewife & 23 & 88.5 \\
\hline Employee & 3 & 11.5 \\
\hline \multicolumn{3}{|l|}{ Breastfeeding Experience } \\
\hline Never Breastfeeding Experience & 26 & 100.0 \\
\hline \multicolumn{3}{|c|}{ Ever Got Information About lactation management } \\
\hline Never & 22 & 84.6 \\
\hline Ever & 4 & 15.4 \\
\hline
\end{tabular}

Age

Based on the results of research conducted by researchers, most respondents aged 20-25 years were $53.8 \%$ or 14 respondents. According to Perry and Potter (2005), the age of 20-25 years is the age of early adulthood, named one of the tasks of its development is to develop intimate relationships through marriage and obtain offspring. So it can be concluded that early adulthood is the time of the formation of a new family to obtain offspring so that this family is mostly the first child or primipara. According to Setiawati's research shows that there is a relationship between maternal age and the practice of exclusive breastfeeding, with a value of $\mathrm{p}=$ 0.039. This is not in line with Aggrita's research in Medan showing that there is no significant relationship between maternal age and exclusive breastfeeding. (Ariyanti Saleh, 2017).

\section{Education}

The education of primiparous mothers in this research was mostly junior high school education of $46.2 \%$ or 12 respondents. Mother's education greatly influences how a person acts and looks for causes and solutions in his life. Highly educated people will usually act more rationally. The higher a person's level of education, the easier it is to obtain information, so the mother's ability to think more rationally. (E.S, 2015)

\section{Work}

In this research, the majority of respondents worked as housewives as much as $88.5 \%$ (23 respondents). Mothers who do not work generally carried out routine tasks as a housewife, so the experience and information obtained is limited compared to working mothers, working mothers will exchange information and knowledge with their peers. (Triana Sari, 2018).

\section{Breastfeeding experience}

Besides the work that most influences the success of lactation is the experience of breastfeeding. Most of the mothers in this research had never breastfeed $100 \%$ or 26 respondents. Primiparous mothers do not have breastfeeding experience different from primigravida who already have experience in breastfeeding skills, with previous breastfeeding experience, the skills and 
knowledge will be more (Ansik Khoiriyah, 2011).

\section{Have been informed about lactation management}

The main factor influencing is the provision of information. Most of the respondents in this research had never received breastfeeding information as much as $84.6 \%$ (22 respondents). Post partum mothers can immediately breastfeed their babies are also influenced by the experience and information obtained. This is consistent with Salmon E's theory that knowledge is related to the amount of information a person has. For information received, we need a perception, namely the process of giving meaning to sensations so that humans gain new knowledge (Rahmat, 2002). The longer a person experiences something, the experience will increase because that person will look for solutions to the things they experience. (Triana Sari, 2018)

Table 2

The Influence of Modeling Approaches Against Primipara's Knowledge of Lactation Management

\begin{tabular}{|c|c|c|c|c|c|c|c|}
\hline \multirow{4}{*}{$\begin{array}{l}\text { Changes in knowledge before and } \\
\text { after the intervention }\end{array}$} & \multicolumn{6}{|c|}{ Knowledge } & \multirow{3}{*}{$\alpha$ sig. } \\
\hline & \multicolumn{2}{|c|}{ Increase } & \multicolumn{2}{|c|}{ Decrease } & \multicolumn{2}{|c|}{ Constant } & \\
\hline & $\mathbf{N}$ & $\%$ & $\mathbf{N}$ & $\%$ & $\mathbf{N}$ & $\%$ & \\
\hline & 14 & 53.9 & 1 & 3.8 & 11 & 42.3 & 0,001 \\
\hline
\end{tabular}

The knowledge of the majority of respondents prior to lactation management modeling still had insufficient knowledge of $80.8 \%$ or 21 respondents and after lactation management modeling the lack of knowledge decreased to $30.8 \%$ or in other words good knowledge increased from $19.2 \%$ to $69.2 \%$. From the Wilcoxon test results it is known that of the 26 respondents, 14 respondents showed an increase in knowledge, 11 people did not change and 1 respondent experienced a decrease after being given an experiment. The statistical analysis results with the Wilcoxon test obtained p-value of 0.001 ( $\mathrm{p}$ $<0.05$ ), meaning that there are differences in knowledge before and after the lactation management modeling approach. So that Ho is rejected, which means there is a significant influence on lactation management modeling.

This is in line with research conducted by Ariyanti (2017) that a factor that can also affect knowledge is the provision of counseling or health education provided by health workers. Health education is one that affects the increase in maternal knowledge, so the more often mothers get health education, the more mothers get information that can indirectly increase their knowledge (Rainy Tri Kurniingtyas, 2017). A person's knowledge can be influenced by several factors including education, mass media or information, social economy, environment, age, and experience (Notoatmodjo, 2003).

Table 3

The Influence of Modeling Approaches Against Primipara's Skill of Lactation Management

\begin{tabular}{|c|c|c|c|c|c|c|c|}
\hline \multirow{4}{*}{$\begin{array}{l}\text { Skill responden before and after } \\
\text { intervention }\end{array}$} & \multicolumn{6}{|c|}{ Keterampilan } & \multirow{3}{*}{$\alpha$ sig. } \\
\hline & \multicolumn{2}{|c|}{ Increase } & \multicolumn{2}{|c|}{ Decrease } & \multicolumn{2}{|c|}{ Tetap } & \\
\hline & $\mathbf{N}$ & $\%$ & $\mathbf{N}$ & $\%$ & $\mathbf{N}$ & $\%$ & \\
\hline & 22 & 84.6 & 1 & 3.8 & 3 & 11.6 & 0,000 \\
\hline
\end{tabular}

*Wilcoxon Test 
The results showed that almost all respondents before doing lactation management modeling had less skills as much as $92.3 \%$ or 24 respondents or only $7.7 \%$ who had good skills, but after modeling good lactation management skills increased to $88,5 \%$ or 23 respondents .. The results of statistical analysis with the Wilcoxon test obtained a p-value of $0,000 \quad(p<0.05)$, meaning that there is an influence of lactation management modeling on skills before and after the lactation management modeling approach.

Most of the respondents still lacked the skills before lactation management modeling was carried out, this could be due to lack of breastfeeding experience (primiparous mothers), lack of information and had never obtained information about lactation management before. The educational background of most primpara mothers is junior high school which still tends to have less information than people who have high education.

In line with Ansik's research (2017) lactation skills are also influenced by parity. In general, puerperal women with parity of more than two (multipara and grandemultipara) showed that the puerperal mother's knowledge about puerperal care (correct how to suckle, early mobilization) is better than postpartum mothers who first gave birth, low maternal education also affects how to give ASI because the higher education enables a person to more easily receive new information or knowledge including how to breastfeed properly (Ansik Khoiriyah, 2011)

After lactation management modeling, there was an increase in primipara regarding the accuracy in carrying out latency management. So when they finish providing health education with modeling researchers reiterate important points that must be implemented properly and correctly when doing lactation management.
Research conducted by Saraswati (2014) also mentions that mothers' skills in lactation management in the first week are getting better after receiving counseling about proper breastfeeding. The statement is in accordance with the theory which states that the purpose of health education or education is to change the behavior of individuals, groups and communities towards positive things in a planned manner through the learning process. The skills of post partum mothers before being given guidance and after being given guidance occur because mothers already have independence in breastfeeding that is obtained from the learning process (Ariyanti Saleh, 2017).

The Effect of Modeling Approaches Against Primipara's Mother's Knowledge and Skills About Lactation Management.

The results showed that of 26 respondents, 14 respondents showed an increase in knowledge of respondents who experienced a decrease after being given treatment. The statistical analysis results with the Wilcoxon test obtained $\mathrm{p}$-value of 0.001 ( $\mathrm{p}<0.05)$, meaning that there are significant differences in knowledge before and after the lactation management modeling approach.

In line with research conducted by Saraswati (2014) that the mother's knowledge after counseling with a modeling approach experienced a very significant increase in knowledge and there were mean differences between before and after the provision of health education and the attitude of nursing mothers in exclusive breastfeeding.

Health education can be done in various ways, including by providing videos and providing simulations. Benjamin Bloom (1908) divides behavior into three domains according to educational goals, namely a) cognitive, b) affective, c) psychomotor. In its development, this theory was modified to measure educational outcomes into a) knowledge, b) attitude, c) practice or action. Counseling with simulation is one of the 
counseling methods that can influence knowledge and attitudes. Direct simulation in the learning process can help in remembering the material that has been given reaches $90 \%$ because the information obtained from the simulation can be received through vision and hearing (Master K. Edgar, n.d.). With modeling methods primipara mothers will understand more directly because in counseling researchers directly demonstrate the correct management of lactation.

The results of skills research on lactation management of 26 respondents, found 22 respondents showed an increase in skills, 3 permanent respondents and 1 respondent decreased after being given an experiment. The results of statistical analysis with the Wilcoxon test obtained p-value of 0.001 ( $p$ $<0.05$ ), meaning that there is an influence of lactation management modeling on skills before and after the lactation management modeling approach.

The modeling method according to Soeratno (2008) is a form of giving method which is arranged in such a way that the learning process is carried out by groups or communities. With modeling there is a twoway interaction, namely between the speaker and the participants, so that concentration and attention can not be distracted because the speaker can master the environment, through direct practice. In this method the speaker participants can observe, pay attention, and practice the right one directly so the skills will improve. The modeling method provides opportunities in a guided and independent manner, having extension participants try out the meaning of the health education process provided, so they remember the process that has been taught. This is in line with research conducted by (Saraswati, 2014) which states that there is an effect of counseling by correct breastfeeding on the skills of breastfeeding for the first week of postpartum mothers at PKU Muhammadiyah Hospital Yogyakarta with a significance value of $0.008(p<0.05)$ which means there is a meaningful relationship between counseling and breastfeeding skills. Likewise with the results of research conducted by Sari (2016) states that there is a significant influence in providing counseling with demonstration methods on the ability of breastfeeding mothers with the statistical test values obtained Sig. 2-tailed $0.00<0.05$. (Hardianti, 2017).

\section{CONCLUSIONS AND SUGGESTIONS}

From the results of the research it was found that the majority of respondents aged 20-25 years have junior high school education, work as housewives, all mothers have never breastfed and most mothers have never received breastfeeding education for.

Before being given health education, some primiparous mothers had less knowledge and skills in lactation management. Through health education with a modelling approach proven to be able to improve the knowledge and skills of primiparous mothers in lactation management.

The results of this research can be useful for nurses or health workers, nursing students, especially child nursing. For primipara mothers to continue to increase knowledge and utilize the knowledge gained and improve the knowledge and skills of primipara mothers about lactation management as well as for health workers in the perinatology room to further enhance health promotion of lactation management through modeling, so as to improve more optimal services to the community and improve baby's health with exclusive breastfeeding. 


\section{DAFTAR PUSTAKA}

Ansik Khoiriyah. (2011). Hubungan Antara Paritas Dengan Keterampilan Menyusui Yang Benar Pada Ibu Nifas. Midpro, 2. Retrieved from http://scholar.google.co.id/scholar?hl=i d\&as_sdt $=0 \% 2 \mathrm{C} 5 \& \mathrm{q}=$ Hubungan+antar a+paritas+dengan+keterampilan+meny usui+yang+benar\&btnG=\#gs_qabs\&u= $\% 23 \mathrm{p} \% 3 \mathrm{D} 5 \mathrm{IJStCqjyH} 8 \mathrm{~J}$

Arini, H. (2012). Mengapa Seorang Ibu Harus Menyusui. Yogyakarta.

Ariyanti Saleh. (2017). Pengaruh pemberdayaan ibu dalam perawatan bayi melalui pendekatan modeling. MKMI, 13 No.2. Retrieved from scholar.google.co.id/scholar?hl=id\&as_ $\mathrm{sd}=0 \% 2 \mathrm{C} 5 \mathrm{\& q}=$ Pengaruh + pemberdaya an + ibu+dalam $+\&$ oq $=$ Pengaruh $+\# d=g s$ _qabs\&u=\%23p\%3DLQ1qVFxUGMJ

Astuti, I. (2018). Pemberian ASI Eksklusif di Indonesia Hanya 35\%. Retrieved from http://m.mediaindonesia.com/amp_deta il/175814-pemberian -asi-eksklusif-diindonesia-hanya-35

Bandura, A. (1977). Social Learning Theory. Englewood Cliffs,. NJ: Prentice Hal. Retrieve from: https://scholar.google.co.id/citations?hl $=$ id\&user=muejNL8AAAAJ\#d=gs_md cita-

$\mathrm{d} \& \mathrm{u}=\% 2$ Fcitations \%3Fview_op \%3Dvi ew_citation\%26hl\%3Did\%26user\%3D muejNL8AAAAJ\%26citation_for_vie w\%3DmuejNL8AAAAJ\%3AyJjnfzR0 HrkC\%26tzom\%3D-420

Dinkes Jawa Timur. (2016). Profil Kesehatan Provinsi Jawa Timur Tahun 2016. Retrieved from http://www.google.com/url?sa=t\&sourc es/download/profil/PROFIL_KES_PR OVINSI_2016/15_jatim_2016.pdf\&ve $\mathrm{d}=2$ ahUKEwiCq5Tx

Dinkes Kab. Bondowoso. (2018). Profil
Kesehatan Provinsi Kabupaten Bondowoso. Retrieved from http://www.google.com/url?sa=t\&sourc $\mathrm{e}=$ web\&rct=j\&url=http://dinkes.bondo wosokab.go.id/\&ved=2ahUKEwjp3K7 e1q3kAhXw8HMBHd2xBrAQFjAAeg QlBhAC\&usg=AOvVaw0O5QkVMcX VVxD-mmOiOSKz

Dwi, S. P. (2012). Buku Pintar ASI Ekslusif. Yogyakarta.

E.S, W. (2015). Asuhan Kebidanan Pada Kehamilan. Yogyakarta: Pustaka Baru Press.

Hardianti. (2017). Pengaruh Penyuluhan Melalui Metode Simulasi / Modeling DAn Audiovisual Medeling Terhadap Tingkat Keterampilan Menggosok Gigi Pada Murid SD Inpres Canbaya IV. Retrieved from http://www.google.com/url?sa=ta\&sour ce=web\&rct=j\&url=http://repositori.ui $\mathrm{n}$ alauddin.ac.id/5290/1/Hardianti.pdf\&v ed=2ajUKEwiX89qz667kAhWCfn0K $\mathrm{Hb}-$

HB1MQFjAAegQlBhAC\&usg=AOvV aw2ncyTLWrFxOTNV-1euN-o4

InfoDatin. (2018). Situasi dan Analisis ASI Eksklusif. Retrieved from http://www.google.com/url?sa=t\&sourc $\mathrm{e}=\mathrm{web} \& \mathrm{rct}=\mathrm{j} \& u r l=\mathrm{http}: / / \mathrm{www}$.depkes. go.id/download.php\%3File\%3Ddownlo $\mathrm{ad} /$ pusdatin/infodatin/infodatinasi.pdf\&ved $=2$ ahUKEwiz5aqs $163 \mathrm{AhV}$ I7nMBHbvJCn0QFjACegQICRAH\&u sg=AvVaw2KzG0RVTM34djzSFc_39 $\mathrm{H} 3$

Master K. Edgar. (n.d.). Dale's Pyramid of Learning In Medical Education:A Literature Review. Med Teach, 35, e1584-93.

Notoatmodjo, S. (2003). Pengantar Pendidikan Kesehatan Dan Ilmu 
Perilaku. Jogyakarta: PT. Rineka Cipta. retrieve from: https://scholar.google.co.id/scholar?clu ster $=14243663307524455809 \& \mathrm{hl}=\mathrm{id} \&$ as_sdt $=2005 \&$ sciodt $=0,5$

Notoatmodjo, S. (2014). Ilmu Perilaku Kesehatan. Jakarta: Rineka Cipta.

Nursalam. (2014). Metode Penelitian Ilmu Keperawatan. Jakarta: Salemba Medika. retrieve from: http://eprints.ners.unair.ac.id/982/

Rainy Tri Kurnianingtyas. (2017). Pengaruh Pendidikan Kesehatan Tentang Manajemen Laktasi Terhadap Efikasi Diri Menyusui Pada Ibu Primigravida TRimester III. Retrieved from http://scholar.google.co.id/scholar?hl=i d\&as_sdt=0\%2C5\&q=Pengaruh+pendi dikan+kesehatan+tentang+manajemen +Laktasi+terhadap+efikasi+diri+meny usui+pada+ibu+primigravida+Trimeste $\mathrm{r}+\mathrm{III} \& \mathrm{btnG}=\# \mathrm{~d}=\mathrm{gs} \_\mathrm{qabs} \& \mathrm{u}=\% 23 \mathrm{p} \% 3$ DFIc4S6iwWKYJ

Saraswati, E. dan M. (2014). Pengaruh Penyuluhan Cara Menyusui yang Benar Terhadap Perilaku Pemberian ASI Minggu Pertama pada ibu Nifas di RS PKU Muhammadiyah Yogyakarta. Retrieved from http://schola.google.co.id/scholar?hl=id \&as_sdt=0\%2C5\&q=Pengaruh=Penyul uhan+cara+menyusui+yang+benar+ter hadap+perilaku+pemberian+ASI+ming gu+pertama+pada+ibu+nifas + di + pku+ Muhammadiyah+yoyakarta\&btnG=\#d= gs_qabs\&u=\%23p\%3DAcIFe5_wMckJ

Triana Sari. (2018). Hubungan Pengetahuan Tentang Manajemen Laktasi Dengan Sikap Ibu Post Partum Dalam Proses Menyusui Di Ruang Bersalin RS Panti Waluya Malang. Ilmiah Keperawatan 3(3). Retrieved from http://scholar.google.co.id/scholar?look up $=0 \& q=$ Hubungan + pengetahuan+tent ang+manajemen+laktasi+dengan+sikap $+\mathrm{ibu}+$ post $+\& \mathrm{hl}=\mathrm{id} \& \mathrm{as} \_\mathrm{sdt}=0,5 \# \mathrm{~d}=\mathrm{gs}$ _
qabs\&u=\%23p\%3D9vXWj7dCwXwJ

Wattimena, I., \& Werdani, Y. D. W. (2015). Manajemen Laktasi dan Kesejahteraan Ibu Menyusui. Jurnal Psikologi, 42(3), 231. https://doi.org/10.22146/jpsi.9911

Zaidin Ali. (2010). Dasar-Dasar dan Promosi Kesehatan. Jakarta: Trans Info Medika. 